\title{
The crown-filament pump of the suspension- feeding polychaete Sabella penicillus: filtration, effects of temperature, and energy cost
}

\author{
Hans Ulrik Riisgård, Nils Mynster Ivarsson \\ Institute of Biology, Odense University, Campusvej 55, DK-5230 Odense M, Denmark
}

\begin{abstract}
The energetics of the ciliary crown-filament pump were studied for the suspensionfeeding polychaete Sabella penicillus. Maximum filtration rate expressed as the clearance capacity $(\mathrm{F}$, $\mathrm{l} \mathrm{h}^{-1}$ ind $^{-1}$ ) as a function of body size (W, g dry wt) was: $\mathrm{F}=13.62 \mathrm{~W}^{0.24}$. The filtration rate was high and constant at algal (Rhodomonas sp.) concentrations below about $4 \times 10^{3}$ cells $\mathrm{ml}^{-1}$, but at higher concentrations the gut capacity was probably exceeded thus leading to a reduced filtration rate. Oxygen consumption ( $\mathrm{R}, \mathrm{ml} \mathrm{O}_{2} \mathrm{~h}^{-1}$ ind. $^{-1}$ ) as a function of size was: $\mathrm{R}=0.13 \mathrm{~W}^{0.66}$. The water-processing capacity of a 'standard' $65 \mathrm{mg}$ dry wt $S$. penicillus was estimated as $354 \mathrm{l}$ of water filtered per $\mathrm{ml}$ of oxygen consumed. This suggests that the polychaete is adapted to live in waters with extremely low algal concentrations. Filtration rate as a function of temperature was measured in 2 size groups of worms. The relationship fitted straight lines and it was found that the viscosity effect may explain the whole correlation between filtration rate and temperatures between 5 and $20^{\circ} \mathrm{C}$. The operating point, $\mathrm{O}_{\mathrm{p}}$ of the crown-filament pump was determined by equating pump characteristic and system characteristic, $\Delta \mathrm{H}_{\mathrm{p}}=\Delta \mathrm{H}_{5}$. The system characteristic was calculated as the sum of the 2 major contributions, namely the pressure drop across the pinnule-lattice of the crown-filaments, $\Delta \mathrm{H}_{1 \mathrm{pc}}$ and the kinetic loss, $\Delta \mathrm{H}_{\mathrm{kex}}$ in the water leaving each crown-filament, which was regarded as one of a series of parallel 'pump units' The calculated operating point and components for e.g. $15^{\circ} \mathrm{C}$ were: $\mathrm{O}_{\mathrm{p}}=\Delta \mathrm{H}_{\mathrm{ipc}}+\Delta \mathrm{H}_{\mathrm{kex}}=$ $0.0222865+0.000065=0.0224 \mathrm{~mm} \mathrm{H}_{2} \mathrm{O}$. The mechanical work done by the pump (pumping power) was $0.451 \mu \mathrm{W}$, compared to a total metabolic energy expenditure of $\mathrm{R}=112 \mu \mathrm{W}$.
\end{abstract}

\section{INTRODUCTION}

During recent years, several attempts have been made to characterize the pump systems of suspensionfeeding animals in terms of pumping power output and energy expenditures of filtering water. Thus, the bivalve pump (Jørgensen et al. 1986, 1988, Jørgensen \& Riisgård 1988), the ascidian pump (Riisgård 1988b) and the pump of the filter feeding polychaete Chaetopterus variopedatus (Riisgård 1989) have been analysed. The energetics of ciliary filter feeding in ciliates has been studied by Fenchel (1986). In a recent study the effects of temperature were studied in the mussel Mytilus edulis, which was modelled as a viscous, leaky, constant-force pump (Jørgensen et al. 1990). It was found that the filtration rate increased linearly with temperature and that 88 to $97 \%$ of the temperature effect could be ascribed to changed viscosity of seawater.

The aim of the present work was to study the properties and energetics of the ciliary crown-filament pump of the suspension-feeding polychaete Sabella penicillus and to compare it with previous studies of biological pumps. Particular attention was paid to the effect of temperature.

Sabella penicillus lives in a tube, which it builds from suspended mud. The feeding mechanism of Sabella pavonina ( $=S$. penicillus) has been described by Nicol (1931). The feeding organ is composed of 2 lateral lobes which are joined at the base on the dorsal side only. They curve around on either side of the mouth (Orrhage 1980), and each bears numerous filaments which stand out stiffly at regular intervals to form a crown (Fig. 1A). Each filament bears a double row of alternating pinnules (Fig. 1B, C). Water is drawn into the interpinnule canals from the outside by the beating of compound latero-frontal cilia consisting of 5 or 6 cilia (scanning electron micrographs made by Dr Claus Nielsen, University of Copenhagen; unpubl.) (Fig. 1D). Along with this water stream enter suspended food particles, mainly algal cells. By means of an unknown 

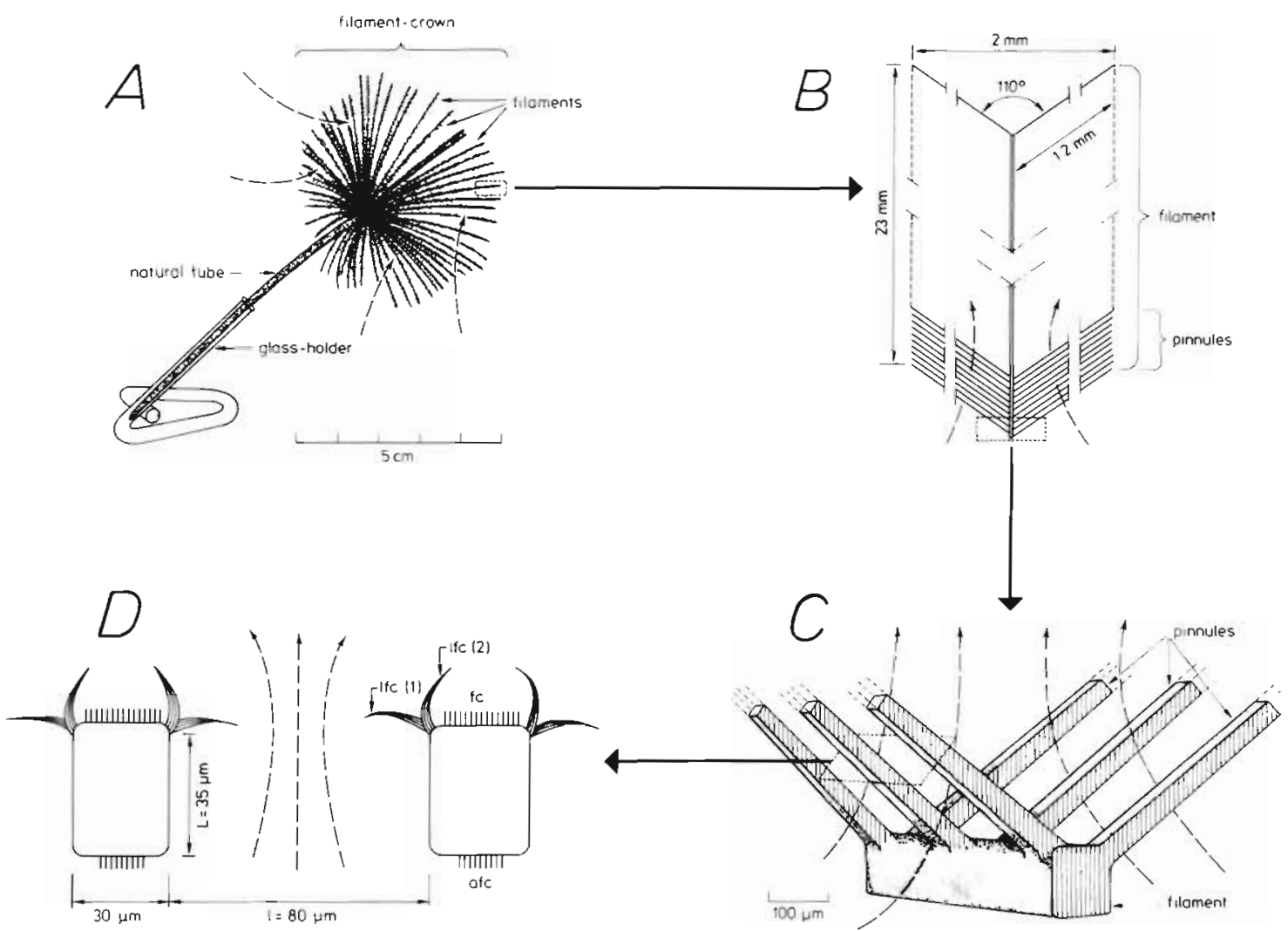

Fig. 1. Sabella penicillus. (A) Glass holder with a worm within its natural tube. The water pumping and particle capturing filament-crown is extended. (B) Crown-filament (23 mm long) with 2 rows of pinnules (1.2 mm long, ca 210 pinnules in each row) branching off from the filament in an angle of $110^{\circ}$ to each other. One filament represents one pump unit; the whole crown pump consists of 39 parallel pump units. (C) Idealized model of section of filament with pinnules. (D) Cross section of 2 pinnules with compound latero-frontal cilia in resting position at end of recovery stroke, lfc(1), and end of active stroke, lfc(2); fc: frontal cilia; afc: abfrontal cilia. Dimensions refer to a 'standard' $65 \mathrm{mg}$ dry wt worm. Dashed lines indicate water flow due to the pumping activity of the latero-frontal cilia. Drawings based on photographs of fresh preparations

mechanism, food particles in the water are retained ('downstream particle retention'; Jørgensen et al. 1984) and carried toward the mouth in a surface current produced by the frontal cilia.

\section{MATERIALS AND METHODS}

Sabella penicillus were collected by SCUBA divers on vertical rock walls at about $30 \mathrm{~m}$ water depth in the Gullmarnfjord on the Swedish west coast. The worms were taken to the nearby Kristineberg Marine Biological Station and kept in running seawater $\left(12^{\circ} \mathrm{C}\right)$ before they were used for experiments at either the Marine Biological Station, at the Marine Pollution Laboratory, Charlottenlund, Denmark, or at the Institute of Biology, University of Odense, Denmark. The worms were transported to Danish laboratories by car in insulated seawater boxes, and then transferred to aquaria with 31 to $33 \%$ S seawater $\left(12\right.$ to $14^{\circ} \mathrm{C}$ ) from the Kattegat or the North Sea. The seawater in the aerated aquaria was changed several times a month, and fresh seawater was used in all experiments. The worms were fed monocultures of Phaeodactylum tricornutum or Dunaliella marina. During periods of up to 4 mo mortality was less than $2 \%$.

For filtration rate measurements, worms within their natural tubes were transferred to holders made of glass tubes (Fig. 1). Single worms or groups of worms could then be transferred to appropriate sized aquaria in which they were placed in a regular and standardized manner prior to clearance experiments.

Filtration rate measurements. The filtration rate was measured as the volume of water cleared of flagellate cells (Dunaliella marina or Rhodomonas sp.; almost spherical cells, 5 to $6 \mu \mathrm{m}$ in diameter) per unit time. The optimum particle size for retention efficiency is ca 3 to $8 \mu \mathrm{m}$ (Jørgensen et al. 1984). Flagellate cells were added to a glass-beaker or an appropriate sized aquarium with a known volume of water ( $V$ ) and a single worm (or groups of worms in 'temperature effect experiments', see below). The reduction in the number 
of particles as a function of time was then followed by taking water samples and subsequently measuring the particle concentration by an electronic particle counter (Coulter Counter, Model TA II or Elzone 80XY). Clearance $(F)$ was determined from the exponential reduction in algal cell concentration as a function of time (always verified as a straight line in a semi-log plot made by hand during the experiment) using the formula: $\mathrm{F}=(\mathrm{V} / \mathrm{nt}) \ln \left(\mathrm{C}_{0} / \mathrm{C}_{\mathrm{t}}\right)$, where $\mathrm{C}_{0}$ and $\mathrm{C}_{\mathrm{t}}$ are the algal concentrations at time 0 and time $t$, respectively, and $n=$ number of worms.

Temperature effect experiments. Sabella penicillus were collected in the Gullmarnfjord in the beginning of July. The clearance capacities of 2 size groups of worms (Group A = 10 'small' and Group B =6 'large' individuals) were measured at different temperatures adjusted at intervals $<5{ }^{\circ} \mathrm{C}$ per day (to prevent disturbance which causes the worm to produce mucus and/or retreat into its tube). Group A and B were kept in aerated aquaria holding 17.6 and $18.9 \mathrm{l}$ of seawater, respectively. After addition of algal cells at an initial concentration of about $4 \times 10^{3}$ cells $\mathrm{ml}^{-1}$, water samples (15 ml) were taken for determination of cell concentration every 5 min by means of a pipette, and the number of active worms was noted. Mean clearance (= filtration rate) was calculated and plotted as a function of temperature.

Respiration experiments. Worms were collected in September and the respiration measurements carried out at the Marine Pollution Laboratory during the following months. Oxygen consumption was measured using the experimental set-up shown in Fig. 2. The worms were placed in respiration chambers of an appropriate size $(14,26,40,66$ and $162 \mathrm{ml})$ according to the size of the worms. The temperature of the respiration chamber was kept constant by submerging the chamber in a constant temperature aquarium $\left(17.3 \pm 0.4^{\circ} \mathrm{C}\right)$. Adequate mixing of the water in the respiration chamber was ensured by the pumping activity of the specimen itself and by the aid of a peristaltic pump (Masterflex, Model 7567-10) recirculating water in 2 tubing systems (Tygon tube, Type 6408-41). One of the tubing systems was connected to a constant temperature cell (Radiometer, Type D 616) in which was mounted an oxygen electrode (Radiometer, Type E 5046). The oxygen electrode continuously recorded the oxygen tension, and the decrease was followed on a pen-recorder. A respiration experiment consisted of a $2 \mathrm{~h}$ measurement, during which the decrease in the oxygen tension was monitored. After $2 \mathrm{~h}$ fresh oxygen-saturated seawater was added and the oxygen tension was followed for another $2 \mathrm{~h}$. All measurements were performed under oxygen tensions between $147 \pm 6$ and $129 \pm 11 \mathrm{~mm} \mathrm{Hg}$ (i.e. 94 to $83 \%$ oxygen saturation). Oxygen uptake was corrected for

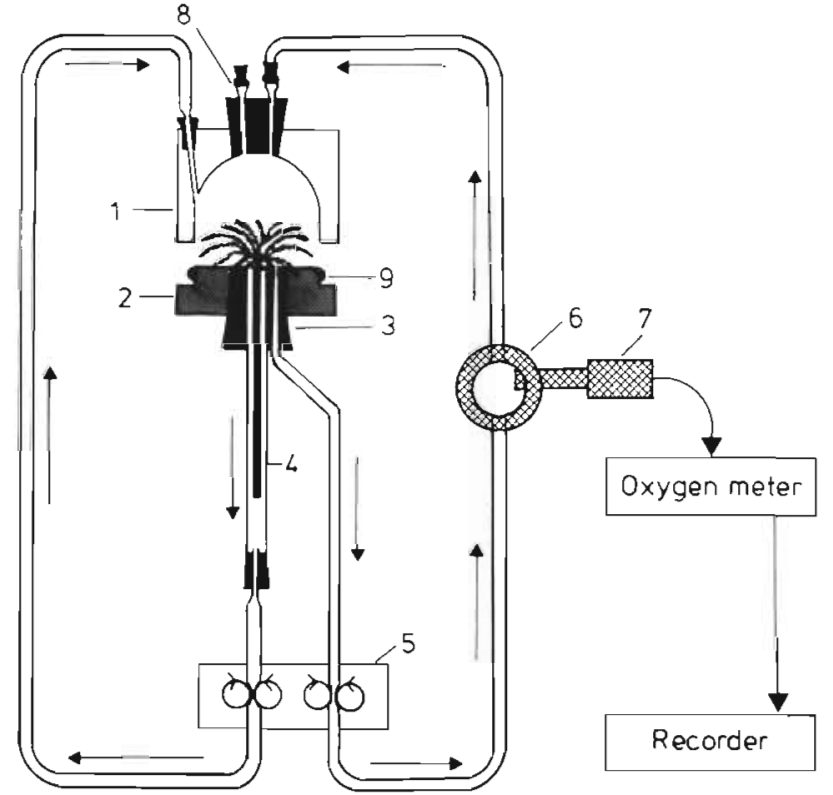

Fig. 2. Experimental set-up used for respiration measurements of Sabella penicillus. (1) Transparent plexiglass cupola which can be pushed down on a circular PVC-base (2) in which is inserted a silicone stopper (3) holding a glass tube (4) with the worm. A peristaltic tubing-pump (5) recirculates water through both the glass tube and a constant temperature cell (6) with an oxygen electrode (7). A hypodermic needle (8) is used for draining surplus water when the respiration chamber is closed. An O-ring of rubber (9) ensures that the plexiglasscupola and the PVC-base is tight

each individual by following the oxygen decrease in a control experiment performed with the empty worm tube.

Constants and conversion factors. The following physical constants and conversion factors were used: density of seawater $\left(35 \%\right.$ S), $\rho=1.028 \mathrm{~g} \mathrm{~cm}^{-3}$ at $5{ }^{\circ} \mathrm{C}$; 1.027 at $10^{\circ} \mathrm{C} ; 1.026$ at $15^{\circ} \mathrm{C} ; 1.025$ at $20^{\circ} \mathrm{C}$; kinematic viscosity, $v=1.562 \times 10^{-6} \mathrm{~m}^{2} \mathrm{~s}^{-1}$ at $5^{\circ} \mathrm{C} ; 1.350 \times 10^{-6}$ at $10^{\circ} \mathrm{C} ; 1.184 \times 10^{-6}$ at $15^{\circ} \mathrm{C} ; 1.056 \times 10^{-6}$ at $20^{\circ} \mathrm{C}$; acceleration due to gravity, $g=980.7 \mathrm{~cm} \mathrm{~s}^{-2} ; 1 \mathrm{ml} \mathrm{O}_{2}=$ $5333 \mu \mathrm{W}$. The expressions for density and kinematic viscosity were calculated from Wheaton (1977). When no references are given for formulae or concepts these matters may be found in general textbooks (e.g. Leyton 1975, Vogel 1981, Fox \& McDonald 1985).

\section{RESULTS AND DISCUSSION}

\section{Filtration and respiration}

Two series of grazing experiments each with one individual of Sabella penicillus kept in an aerated aquarium, to which were added algal cells at different concentrations at different times, are shown in Figs. 3 


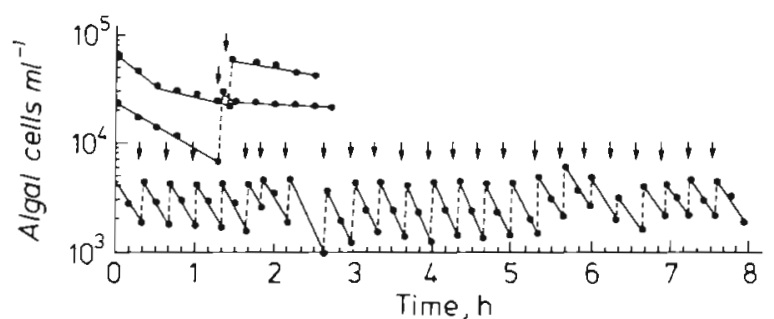

Fig. 3. Sabella penicillus. Reduction in concentration of algal cells due to grazing by a single worm ( $56 \mathrm{mg}$ dry wt) in an aerated aquarium. Three experiments on different days are shown. Arrows indicate additions of algal suspension

and 4 . Reduction in the concentration of algal cells due to grazing of the worm is rapid and constant (i.e. the clearance, expressed by the slope of the line fitted for the algal reduction in the semi-logarithmic plot, is high and appears constant) for concentrations ranging between about $2 \times 10^{3}$ and $4 \times 10^{3}$ cells $\mathrm{ml}^{-1}$. At algal concentrations above about $10^{4}$ cells $\mathrm{ml}^{-1}$ the filtration rate is reduced. At the 2 highest algal concentrations in Fig. 3 the filtration rate is relatively high after the first algal addition, but then becomes very low after the second addition. When the worm is allowed to graze the algal concentration down over a prolonged period (Fig. 4) the grazing rate gradually becomes higher. It

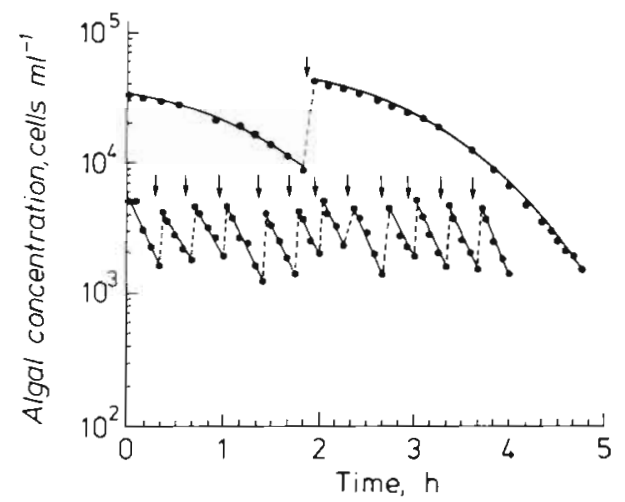

Fig. 4. Sabella penicillus. Reduction in algal cell concentration due to grazing by a single worm ( $82 \mathrm{mg}$ dry wt) in an aerated aquarium. Two experiments on different days are shown. Arrows indicate additions of algai suspension

may be concluded that the clearance is high and constant (up to at least $8 \mathrm{~h}$ ) at algal concentrations below about $4 \times 10^{3}$ cells $\mathrm{ml}^{-1}$, but at higher concentrations it may be suggested that the gut capacity is exceeded thus leading to a reduced filtration rate.

The maximum filtration rate expressed as the clearance capacity (F, $\mathrm{l} \mathrm{h}^{-1}$ ind. $\left.^{-1}\right)$ measured in Sabella penicillus as a function of body size ( $W, g$ dry wt) in algal concentration intervals between $4 \times 10^{3}$ and $2 \times$ $10^{3}$ cells $\mathrm{ml}^{-1}$ is shown in Fig. 5. The equation for the regression line is: $\left.F=13.62 \mathrm{~W}^{0.24} \mathrm{r}=0.985\right)$. The

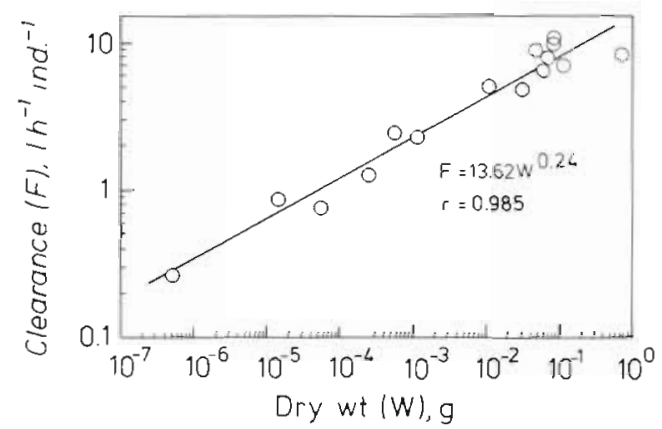

Fig. 5. Sabella penicillus. Clearance capacity as a function of body size at $13^{\circ} \mathrm{C}$. Regression line is shown

equation for the total filament length of all crownfilaments $(\mathrm{L}, \mathrm{cm})$ as a function of body size ( $\mathrm{W}, \mathrm{g}$ dry $\mathrm{Wt}$ ) is: $\mathrm{L}=437 \mathrm{~W}^{0.32}\left(\mathrm{r}=0.999, \mathrm{n}=15, \mathrm{~W}\right.$ interval: $5 \times 10^{-7}$ to $0.136 \mathrm{~g})$. Because the total crown-filament length may be regarded as an indirect measure of the filtration rate, the exponent 0.32 for total filament length may be compared to the exponent 0.24 for filtration rate as a function of size. The agreement between the 2 slopes is reasonably good.

Clearance as a function of temperature in 2 size groups of worms is shown in Fig. 6. The relationship fits a straight line in both groups. The slopes of the regression lines are 2.17 and 1.68 in Group A and Group B, respectively.

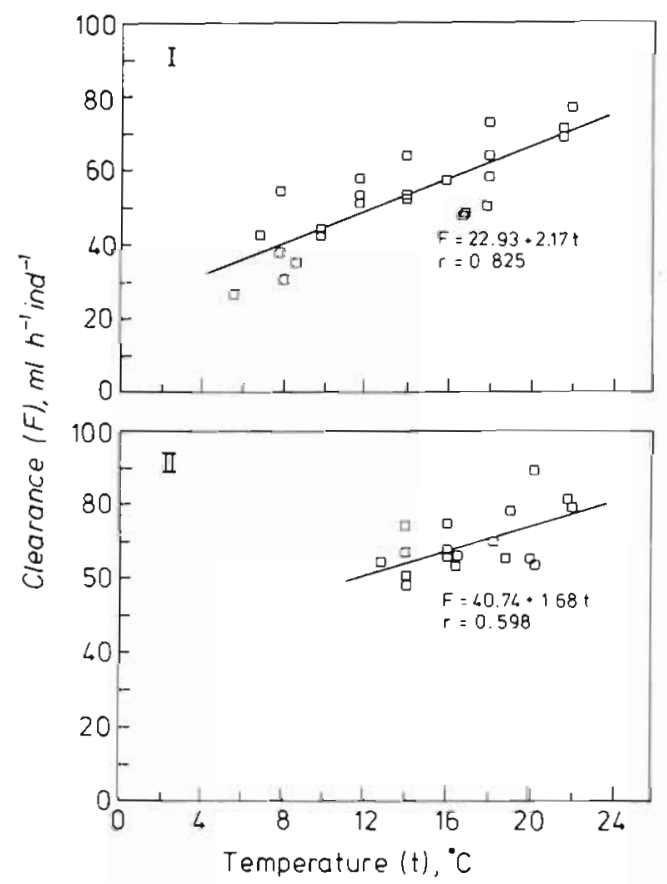

Fig. 6. Sabella penicillus. Mean clearance as a function of temperature in 2 groups of worms (I) Group A: 10 individuals, $65 \pm 30 \mathrm{mg}$ dry wt; (II) Group B: 6 individuals, $120 \pm 40 \mathrm{mg}$ dry wt. Regression lines are shown 
Fig. 7 shows the oxygen consumption $\left(\mathrm{R}, \mathrm{ml} \mathrm{O}_{2} \mathrm{~h}^{-1}\right.$ ind. ${ }^{-1}$ ) in Sabella penicillus as a function of size (W, g dry $w \mathrm{t})$. The equation for the regression line is: $\mathrm{R}=$ $0.13 W^{0.66}(r=0.985)$. During several of the respiration experiments the worm frequently withdrew into its

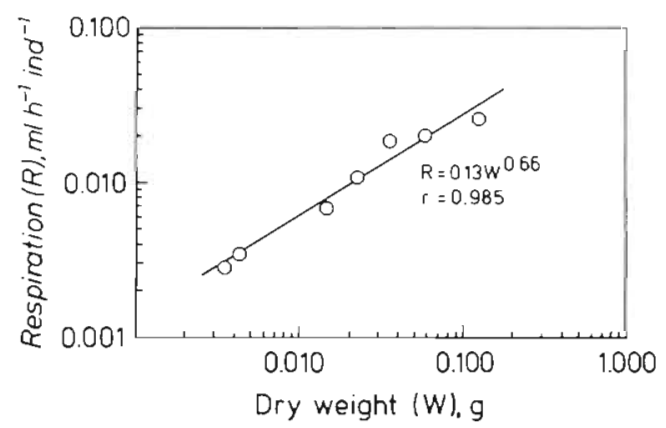

Fig. 7. Sabella penicillus. Respiration as a function of body size at $17.3+0.4{ }^{\circ} \mathrm{C}$. Regression line is shown

tube, but no difference in oxygen uptake was noted. This indicates that the crown of $S$. penicillus is not a respiratory organ, but may exclusively serve feeding purposes. A few observations were made with the use of a video system connected to an inverted microscope on which was placed a transparent plexiglass beaker with seawater and a small (ca $2 \mathrm{~cm}$ long) $S$. penicillus. The worm was in its natural tube, fixed in an inclined position (by means of a holder made of a piece of glasstube). It was observed that the water-pumping laterofrontal cilia on the pinnules of the filaments did not beat when the crown was more or less withdrawn into the tube - or even when the crown was fully extended but not wide open. Since we could not detect any difference in oxygen consumption between the undisturbed, water-pumping worm and the disturbed worm with resting latero-frontal cilia, it seems reasonable to conclude that the beating of the latero-frontal cilia contributes only marginally to the total respiration rate.

The respiration rate of Sabella penicillus measured in this study (Fig. 7) may be compared to that of other suspension-feeding polychaetes. Kayar (1978) measured the oxygen uptake in S. melanostigma. By converting wet body weight to dry weight $(5: 1)$ Kayar's data conform to the following equation for respiration $\left(\mathrm{R}, \mathrm{ml} \mathrm{O}_{2} \mathrm{~h}^{-1}\right)$ as a function of dry weight (W, g): $\mathrm{R}=$ $0.38 W^{1.02}$ (W interval: 2 to $160 \mathrm{mg}$ ). Riisgård (1989) measured respiration $\left(\mathrm{R}, \mu \mathrm{O} \mathrm{O}_{2} \mathrm{~h}^{-1}\right)$ as a function of dry body weight ( $W, \mathrm{mg}$ ) of Chaetopterus variopedatus and found the relationship: $\mathrm{R}=1.90 \mathrm{~W}^{0.59}$ (W interval: 274 to $886 \mathrm{mg}$ ). The estimated respiration rate of $S$. melanostigma and $C$. variopedatus, each of $65 \mathrm{mg}$ dry weight, is found to be 23.4 and $22.3 \mu \mathrm{O}_{2} \mathrm{~h}^{-1}$, respectively. In the present study a 'standard' $65 \mathrm{mg}$ dry weight worm has a respiration rate of $21 \mu \mathrm{l} \mathrm{O}_{2} \mathrm{~h}^{-1}$. This value is close to those found for $S$. melanostigma and $C$. variopedatus.

The individually measured clearance capacities (Fig 5) are systematically higher than the mean clearances measured in the 2 groups with 10 and 6 individuals (Fig. 6). The lower values may be due to insufficient mixing in the aquaria. Instantaneous mixing of the total water volume is a prerequisite for the use of the clearance formula, and this condition is more easily approached with only one individual than with groups of worms. As the error of underestimation is systematic, the slopes of the lines in Fig. 6 are believed to describe the true relationship between clearance and temperature. An approximate slope of 2 for the

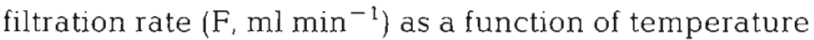
$\left(\mathrm{t},{ }^{\circ} \mathrm{C}\right.$ ) for the 'standard' worm was adopted and the relation expressed as:

$$
F=90+2 t
$$

The following discussion considers a 'standard' $65 \mathrm{mg}$ dry weight Sabella penicillus with a clearance capacity, $\mathrm{F}=7.44 \mathrm{l} \mathrm{h}^{-1}$ at $17^{\circ} \mathrm{C}$.

The amount of water that a temperate zone, nearcoastal, marine suspension feeder must filter to obtain enough food to cover the minimal energy requirements exceeds $10 \mathrm{l}$ of water per $\mathrm{ml}$ of oxygen consumed (Jørgensen 1975). The water-processing capacity of the 'standard' Sabella penicillus is estimated as $354 \mathrm{l}$ of water filtered per $\mathrm{ml}$ of oxygen consumed. This value may be compared to $50 \mathrm{l}$ per $\mathrm{ml}$ of oxygen in Chaetopterus variopedatus (Riisgård 1989) which coexists with $S$. penicillus in the Gullmarnfjord. The 7 -fold difference in water-processing capacity between $C$. variopedatus and $S$. penicillus may reflect differential particle capturing efficiency. C. variopedatus retains particles down to about $1.5 \mu \mathrm{m}$ with $100 \%$ efficiency with its mucous net, while the retention efficiency in the ciliary feeding $S$, penicillus rapidly declines below $3 \mu \mathrm{m}$ (Jørgensen et al. 1984). The high water-processing capacity of $S$. penicillus suggests that the measured clearances are representative of those applying in nature, and further, that the polychaete is adapted to live in waters with extremely low algal concentrations. Throughout its ontogenetic development the mussel Mytilus edulis, which retains particles somewhat less efficiently than S. penicillus (i.e. $4 \mu \mathrm{m}$ particles are retained with $100 \%$ efficiency), processes 15 to $50 \mathrm{l}$ water per ml of oxygen consumed (Riisgård et al. 1980). Thus, the 2 species seem to be adapted to different regimes of suspended food particles, and the present data suggest that $M$. edulis may not be able to live in the same localities as $S$. penicillus. The rapid saturation of the digestive system (i.e. low clearance rates) at algal concentrations above $10^{4}$ cells $\mathrm{ml}^{-1}$ in $\mathrm{S}$. penicillus (Fig. 3 and 4) supports this interpretation. S. penicillus 
seems to process water continously and both the filterand digestive systems are designed to operate optimally at low phytoplankton concentrations. The same adaptation may be found in other suspension-feeding polychaetes, and the use of unnaturally high particle concentrations in filtration experiments may explain the generally low values found for suspension-feeding polychaetes by other workers (Table 1). In a study of Lanice conchilega, Buhr (1976) used an algal concentration of $4 \times 10^{4}$ cells ml ${ }^{-1}$. This is about 10 times the 'saturation' concentration found in the present work for $S$. penicillus (Figs. 3 and 4 ). The very low filtration rates measured by Dales (1969) and Brown (1977) in C. variopedatus have been discussed and partly explained by Riisgård (1989). Presumably, the low filtration rates shown in Table 1 are not representative of the water processing capacities of the species.

A functional response similar to that seen in Figs. 3 and 4 has previously been found in early veliconchia of Mytilus edulis (Riisgård et al. 1980) and veliger larvae of the hard clam Mercenaria mercenaria (Riisgård 1988a) fed Isochrysis galbana cells. At low algal concentrations $\left(2 \times 10^{3}\right.$ to $4 \times 10^{3}$ cells ml $\left.{ }^{-1}\right)$ the clearance of $M$. edulis larvae was high and constant over $8 \mathrm{~h}$. At high algal concentrations (above $2 \times 10^{4}$ ) the clearance capacity was only maintained until the stomach was full. The time at which this took place was indicated by a sharp shift in the relationship between clearance and algal concentration in a semi-logarithmic plot. Similar shifts can be seen in Fig. 3. Other experiments with $S$. penicillus exposed to algal concentrations between $4 \times 10^{3}$ and $10^{4}$ Rhodomonas cells $\mathrm{ml}^{-1}$ have also shown such shifts. The reduction in cell concentration after the gut has been filled probably reflects simultaneous refilling of the gut. This may explain the curves for algal reduction in the experiments with high algal concentrations in Fig. 4.

The present work emphasizes the need for more knowledge about actual algal concentrations in the immediate vicinity of benthic suspension-feeding polychaetes. The food particle concentration in the boundary layer may be extremely low. Benthic suspension feeders seem to have developed filter-, pump- and digestive systems to cope with low algal concentrations. The absence of control of filtration rate as a means to control feeding rates in M. edulis (Jørgensen et al. 1988) stresses the importance of performing laboratory experiments at natural algal concentrations and of interpreting laboratory findings in a meaningful ecophysiological context. The apparently inverse rela-

Table 1. Clearance (= filtration rate) in different suspension-feeding polychaetes. (Body size expressed as wet wt has been converted to dry wt by dividing by 5 )

\begin{tabular}{|c|c|c|c|c|c|c|}
\hline Family & Species & $\begin{array}{l}\text { Dry wt } \\
\text { (mg) }\end{array}$ & $\begin{array}{l}\text { Clea } \\
\left(1 h^{-1}\right)\end{array}$ & $\begin{array}{l}\text { arance } \\
\left(1 \mathrm{~h}^{-1} \mathrm{~g}^{-1}\right)\end{array}$ & $\begin{array}{l}\text { Suspended } \\
\text { particles }\end{array}$ & Source \\
\hline \multicolumn{7}{|c|}{ Terebellidae } \\
\hline & Lanice conchilega & 1.3 & 0.009 & 6.92 & Dunaliella & Buhr (1976) \\
\hline & & 3.6 & 0.011 & 3.13 & & \\
\hline & & 8.1 & 0.013 & 1.63 & & \\
\hline & & 9.5 & 0.013 & 1.41 & & \\
\hline & & 35.0 & 0.026 & 0.75 & & \\
\hline \multicolumn{7}{|c|}{ Serpulidae } \\
\hline & Pomatoceros triqueter & 2.2 & 0.011 & 5.0 & Dunaliella & Klockner (1978) \\
\hline & & 3.7 & 0.027 & 7.3 & Graphite & Dales (1957) \\
\hline & Salmacina dysteri & 0.028 & 0.00029 & 10.4 & Graphite & Dales (1957) \\
\hline & Spirorbis borealis & 0.048 & 0.00023 & 4.8 & & \\
\hline & Hydroides norvegica & 2.46 & 0.0112 & 47 & & \\
\hline \multicolumn{7}{|c|}{ Sabellidae } \\
\hline & Schizobranchia insignis & 200 & 0.35 & 1.75 & Graphite & Dales (1961) \\
\hline & Myxicola infundibulum & 539 & 0.286 & 0.531 & Graphite & Dales (1957) \\
\hline & & $100-500$ & & 2.8 & Thalassiosira & Shumway et al. (1988) \\
\hline & & & & 1.34 & Chroomonas & \\
\hline & & & & 1.04 & Isochrysis & \\
\hline & Sabella penicillus & 37 & 0.073 & 1.973 & Graphite & Dales (1957) \\
\hline & & 65 & 7.1 & 109 & Dunaliella & Present study \\
\hline \multicolumn{7}{|c|}{ Chaetopteridae } \\
\hline & Chaetopterus variopedatus & 50 & 1.08 & 21.6 & Dunaliella & Ruisgẳrd (1.989\}) \\
\hline & & 864 & 0.47 & 0.54 & Graphite & Dales (1969) \\
\hline & & 904 & 1.94 & 2.15 & $?$ & Brown (1977) \\
\hline
\end{tabular}


tionship between algal concentration and filtration rate in, e.g., mussels (Winter 1973, Sprung \& Rose 1988) should not be interpreted as a regulatory mechanism (Riisgård \& Møhlenberg 1979, Jørgensen et al. 1988, 1990). The decrease in filtration rate may simply be due to an overloading of the feeding system when unnaturally high algal concentrations are used in laboratory experiments

\section{Effects of temperature and energy cost}

In order to analyse the ciliary crown-filament pump of Sabella penicillus, dimensions referring to a 'standard' $65 \mathrm{mg}$ dry weight worm were obtained from video recordings and microscope photographs of fresh crown filament preparations. The following dimensions were measured: length of crown-filaments, $L C F=23$ mm; number of crown-filaments, $N=39$ (estimated from the expression: $N=18.94 \mathrm{D}^{0.48}$, where $\mathrm{D}=$ crowndiameter $=2 \times$ LCF); length of pinnules $=1.2 \mathrm{~mm}$; width of pinnules $=30 \mu \mathrm{m}$; height of pinnules, $\mathrm{L}=$ $35 \mu \mathrm{m}$; distance between 2 pinnules, $1=80 \mu \mathrm{m}$; angle between 2 rows of opposite rows of pinnules on the same filament $=110^{\circ}$. From these data and Eq. (1), the mean water velocity $(\mathrm{v})$ between the pinnules at 5,10 , 15 and $20^{\circ} \mathrm{C}$ is estimated to: $\mathrm{v}=1.063,1.169,1.276$ and $1.382 \mathrm{~mm} \mathrm{~s}^{-1}$, respectively.

The operating point, $\mathrm{O}_{\mathrm{p}}$, of the crown-filament pump may be determined by equating pump characteristic and system characteristic (Jørgensen et al. 1986, 1988, Riisgard 1988b, 1989), $\Delta H_{p}=\Delta H_{s}$. The system characteristic in Sabella penicillus is calculated as the sum of only 2 major contributions, namely the pressure drop across the pinnule-lattice of the crown-filaments, $\Delta H_{i p c}$, and the kinetic loss, $\Delta \mathrm{H}_{\mathrm{kex}}$ in the water leaving each crown-filament which may be regarded as one of 39 parallel 'pump units' (Fig. 1).

The structure of the crown-filaments approximates that of a filter consisting of parallel circular cylinders, the pinnules (diameter, $\mathrm{d}=35 \mu \mathrm{m}$ ), with a distance, $\mathrm{l}=$ $110 \mu \mathrm{m}$, between centers of neighbouring cylinders. The model developed by Tamada \& Fujikawa (1957) to predict pressure drop over such filters is used to calculate the pressure drop across the crown-filament:

$$
\Delta \mathrm{H}_{\mathrm{lpc}}=\mathrm{K}_{\mathrm{l}} v \overline{\mathrm{u}} / \mathrm{gd}
$$

where $K_{1}=8 \tau /\left(1-2 \ln \tau+\tau^{2} / 6\right), \tau=d / l, \bar{u}$ is the undisturbed upstream velocity $\left(0.773 \mathrm{~mm} \mathrm{~s}^{-1}\right.$ at $5^{\circ} \mathrm{C}$; 0.850 at $10^{\circ} \mathrm{C} ; 0.928$ at $15^{\circ} \mathrm{C} ; 1.005$ at $20^{\circ} \mathrm{C}$ ). The pressure drop has also been estimated from the experimentally obtained formula of Munson (1988) for estimating pressure drop across square-mesh screens at very low Reynolds number $(\operatorname{Re} \leq 0.1)$ :

$$
\Delta \mathrm{H}_{\mathrm{ipc}}=\mathrm{K}_{2} v \overline{\mathrm{u}} / \mathrm{gd}
$$

where $\mathrm{K}_{2}=4.75\left(1-\alpha^{2}\right) / 2 \alpha^{2}, \alpha=(1-\mathrm{d} / \mathrm{l})^{2}$. The Reynolds number in the present case fulfills the prerequisite for using the formula $(\operatorname{Re}=\bar{u} d / v=0.04)$. The calculated pressure drops found by using both formulae are shown in Table 2. There is fairly good agreement between the 2 set of estimates, and a mean value is used for calculating the operating point.

The kinetic component is calculated from (cf. Jørgensen et al. 1990):

$$
\Delta H_{\text {kex }}=\left(v_{\text {ex }}\right)^{2} / 2 g
$$

where $v_{e x}$ is the mean velocity in the exhalant split of the crown-filament estimated as: (filament volume flow)/(filament 'exhalant area' $=2 \times 23 \mathrm{~mm}$; see Fig. 1) $=(51 / 46)=1.11 \mathrm{~mm} \mathrm{~s}^{-1}$. The calculated components and operating points, $\mathrm{O}_{\mathrm{p}}$, for $5,10,15$ and $20^{\circ} \mathrm{C}$ are

Table 2. Sabella penicillus. Estimated filtration rates from empirically derived expression, Eq. (1), and from Eq. (5), in an optimally

\begin{tabular}{|c|c|c|c|c|}
\hline & $5^{\circ} \mathrm{C}$ & $10^{\circ} \mathrm{C}$ & $15^{\circ} \mathrm{C}$ & $20^{\circ} \mathrm{C}$ \\
\hline \multicolumn{5}{|l|}{ Filtration rate $\left(\mathrm{ml} \mathrm{s}^{-1}\right)$} \\
\hline Eq. (1) & 1.67 & 1.88 & 2.00 & 2.17 \\
\hline Eq. (5) & 1.67 & 1.93 & 2.20 & 2.47 \\
\hline \multicolumn{5}{|l|}{ Head losses $\left(\mathrm{mm} \mathrm{H}_{2} \mathrm{O}\right)$} \\
\hline \multicolumn{5}{|c|}{ Interpinnule canals $\Delta \mathrm{H}_{\mathrm{ipc}}$} \\
\hline Eq. (2) & 0.021663 & 0.020587 & 0.019713 & 0.019040 \\
\hline Eq. (3) & 0.027319 & 0.025963 & 0.024860 & 0.024012 \\
\hline Mean & 0.024491 & 0.023275 & 0.0222865 & 0.021526 \\
\hline Kinetic loss $\Delta H_{\text {kex }}$ & 0.000045 & 0.000055 & 0.000065 & 0.000077 \\
\hline Operating point $O_{p}$ & 0.0246 & 0.0234 & 0.0224 & 0.0217 \\
\hline Pumping power $P_{p}(\mu w)$ & 0.414 & 0.443 & 0.451 & 0.473 \\
\hline Pump work $\mathrm{P}_{p} / \mathrm{R}(\%)$ & 0.370 & 0.396 & 0.402 & 0.423 \\
\hline
\end{tabular}
pumping $65 \mathrm{mg}$ dry weight 'standard' at reference temperatures of $5,10,15$ and $20^{\circ} \mathrm{C}$. The head losses, operating points (Op), power output and pump work $\left(\mathrm{P}_{\mathrm{p}} / \mathrm{R}\right)$ are shown 
shown in Table 2. There is a decrease in the operating point from 0.0246 to $0.0217 \mathrm{~mm} \mathrm{H}_{2} \mathrm{O}$ when the temperature is increased from 5 to $20^{\circ} \mathrm{C}$, and it may be noted that the main contribution to the system resistance is the pressure drop across the pinnule-lattice.

Filtration rates calculated from Eq. (1) at 5, 10, 15 and $20^{\circ} \mathrm{C}$ may be compared to filtration rates at these temperatures, $F_{t}$ estimated by using the expression:

$$
F_{t}=F_{5}\left(v_{5} / v_{t}\right)=1.67\left(v_{5} / v_{t}\right)
$$

From the calculated filtration rates shown in Table 2 it is seen that the viscosity effect may explain the whole correlation between filtration rate and temperature.

The temperature effects on filtration rate in Sabella penicillus may be compared to a recent study on Mytilus edulis by Jørgensen et al. (1990). It was found that 88 to $97 \%$ of the increase in filtration rate in the temperature interval from 5 to $22^{\circ} \mathrm{C}$ was due to change in viscosity. It is interesting to note that the slope of the linear regression of clearance versus temperature in $M$. edulis is lower (about 1.2) than that found in the present work (Fig. 6). The significant kinetic loss in the exhalant siphon of $M$. edulis is more likely to offset increased filtration rate due to reduced frictional loss at higher temperatures than is the case for $S$. penicillus in which the kinetic exit loss is negligible.

The power output, $\mathrm{P}_{\mathrm{p}}$, from the Sabella penicillus pump can be calculated as the product of pumping pressure $\left(\Delta P=\rho g O_{p}\right)$ and filtration rate $(F)$ :

$$
\mathrm{P}_{\mathrm{p}}=\rho g \mathrm{O}_{\mathrm{p}} \mathrm{F}
$$

Pumping power at the 4 reference temperatures is shown in Table 2 . The work done by the pump may be compared to the total metabolic energy expenditure of the 'standard' Sabella penicillus, as expressed by the oxygen consumption $\mathrm{R}=0.021 \mathrm{ml} \mathrm{O}_{2} \mathrm{~h}^{-1}$ which corresponds to $112 \mu \mathrm{W}$. The pump work, $P_{p} / R$, which expresses the mechanical work done by the pump as a percentage of the total metabolic rate, is also shown for the four reference temperatures in Table 2.

The ratio between metabolic and mechanical efficiency of the latero-frontal cilia in Sabella penicillus is not known, but to arrive at an estimate another ciliary suspension-feeding animal may be used for comparison, namely Mytilus edulis. The mechanical pumping power as a percentage of the power generation of the lateral cilia in a $35 \mathrm{~mm}$ 'standard' $M$. edulis may be found by relating the pump power output of $10 \mu \mathrm{W}$ (Jørgensen et al. 1988) to the metabolic rate of $78 \mu \mathrm{W}$ of the cells carrying the water-pumping lateral cilia (Clemmesen \& Jorgensen 1987), i.e. (10/78)100= $13 \%$. By using $13 \%$ as a general estimate of metabolic to mechanical efficiency in ciliary suspension-feeders the percentage of total metabolic power used for water pumping may be found in suspension-feeders belong-

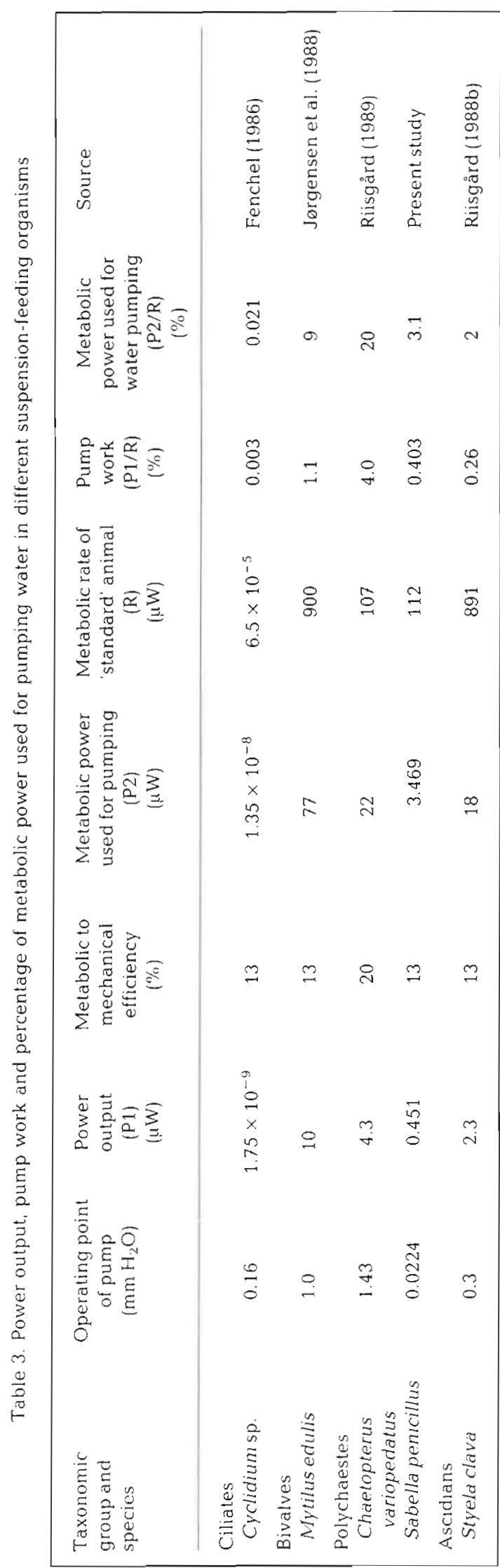


ing to various taxonomic groups (Table 3 ). Only $3.1 \%$ of the total metabolic energy is used for water processing in $S$. penicillus. The generally low values in $\mathrm{Ta}-$ ble 3 suggests that the energetic cost of water pumping is not a restricting factor for the success of suspensionfeeding animals. The pump- and filter systems in different species of suspension-feeders seem to be discretely dimensioned to the biotope to which the animals are adapted. The energetic cost of having a large filtering organ is not likely to be the limiting factor for a suspension feeder even in an extremely meagre environment.

Acknowledgements. Thanks are due to Prof. P. Scheel Larsen and N. Finderup Nielsen, M. Eng, Fluid Mechanics Department, Technical University of Denmark, and Prof. C. Barker Jorgensen, August Krogh Institute, Copenhagen University, for valuable help and comments. Dr V. Forbes at this institute is acknowledged for critically reading the manuscript and for making linguistic corrections. We are grateful to the Kristineberg Marine Biological Station, Sweden, for hospitality and help with collecting of experimental worms. During the laborious temperature-effect study at Kristineberg in June 1989 Dr B. F. Larsen spend a great part of her holiday as a committed and encouraging assistant.

\section{LITERATURE CITED}

Brown, S. C. (1977). Biomechanics of water-pumping by Chaetopterus variopedatus Renier: kinetics and hydrodynamics. Biol. Bull. mar. biol. Lab. Woods Hole 153: $121-132$

Buhr, K.-J. (1976). Suspension-feeding and assimilation efficiency in Lanice conchilega (Polychaeta). Mar. Biol. 38: 373-383

Clemmesen, B., Jørgensen, C. B. (1987). Energetic costs and efficiencies of ciliary filter feeding. Mar. Biol. 94: 445-449 (1987)

Dales, R. P. (1957). Some quantitative aspects of feeding in sabellid and serpulid fan worms. J. mar. biol. Ass. U.K. 36: 309-316

Dales, R. P. (1961). Observations on the respiration of the sabellid polychaete Schizobranchia insignis. Biol. Bull. mar. biol. Lab., Woods Hole $121 \quad 82-91$

Dales, R. P. (1969). Respiration and energy metabolism in annelids. In: Florkin, M., Scheer, B. T. (eds.) Chemical zoology, Vol. IV. Academic Press, New York, p. 93-109

Fenchel, T. (1986). Protozoan filter feeding. Prog. in Protistol. 1: $65-113$

Fox, R. W., McDonald, A. T. (1985). Introduction to fluid mechanics. Wiley \& Sons, Inc., New York

Jørgensen, C. B. (1975). Comparative physiology of suspension feeding. Ann. Rev. Physiol. 30: 391-454

Jørgensen, C. B., Famme, P., Saustrup Kristensen, H., Larsen, P. S., Møhlenberg, F., Riisgård, H. U. (1986). The bivalve pump. Mar. Ecol. Prog. Ser. 34: 69-77

Jørgensen, C. B., Kiørboe, T., Møhlenberg, F., Riisgård, H. U. (1984). Ciliary and mucus-net filter feeding, with special

This article was submitted to the editor reference to fluid mechanical characteristics. Mar. Ecol Prog. Ser 15: 283-292

Jorgensen, C. B., Larsen, P. S., Mohlenberg, F., Riisgărd, H. U. (1988). The mussel pump: properties and modelling. Mar Ecol. Prog. Ser. 45: 205-216

Jørgensen, C. B., Larsen, P. S., Riisgård, H. U. (1990). Effects of temperature on the mussel pump. Mar. Ecol. Prog. Ser (in press)

Jorgensen, C. B., Riisgå̊d, H. U. (1988). Gill pump characteristics of the soft clam Mya arenaria. Mar. Biol. 99: 107-109

Kayar, S. R. (1978). Oxygen uptake and the role of chlorocruorn in Sabella melanostigma (Polychaeta: Sabellidae). Ph.D. thesis, University of Miami. University Microfilms International No.: 7818711

Klöckner, K. (1978). Zur Okologie von Pomatoceros triqueter (Serpulidae, Polychaeta). Helgoländer wiss. Meeresunters $31 \quad 257-284$

Leyton, L. (1975). Fluid behaviour in biological systems Clarendon Press, Oxford

Munson, B. R. (1988). Very low Reynolds number flow through screens. J. Fluids Eng. 110: 462-463

Nicol, E. A. T (1931). The feeding mechanism, formation of the tube and physiology of digestion in Sabella pavonina. Trans. R. Soc. Edinb. 56: 537-597

Orrhage, L. (1980). On the structure and homologues of the anterior end of the polychaete families sabellidae and serpulidae. Zoomorphology 96: 113-168

Riisgård, H. U. (1988a). Feeding rates in hard clam (Mercenaria mercenaria) veliger larvae as a function of algal (Isochrysis galbana) concentration. J. Shellfish Res. 7 $377-380$

Riisgård, H. U. (1988b). The ascidian pump: properties and energy cost. Mar Ecol. Prog. Ser. 47-129-134

Riisgård, H. Li (1989). Properties and energy cost of the muscular piston pump in the suspension feeding polychaete Chaetopterus variopedatus. Mar. Ecol. Prog. Ser. 56: 157-168

Riisgård, H. U., Mohlenberg, F. (1979). An improved automatic recording apparatus for determining the filtration rate of Mytilus edulis as a function of size and algal concentration. Mar Biol. 52: 61-67

Riisgård, H. U., Randløv, A., Kristensen, P. S. (1980). Rates of water processing, oxygen consumption and efficiency of particle retention in veligers and young post-metamorphic Mytilus edulis. Ophelia 19: $37-47$

Shumway, S., E., Bogdanowicz, C., Dean, D. (1988). Oxygen consumption and feeding rates of the sabellid polychaete Myxicola infundibulum (Renier). Comp. Biochem. Physiol. 90A: $425-428$

Sprung, M., Rose, U. (1988). Influence of food size and food quantity on the feeding of the mussel Dreissena polymorpha. Oecologia (Berl.) 77: 526-532

Tamada, K., Fujikawa, H. (1957). The steady two-dimensional flow of viscous fluid at low Reynolds numbers passing through an infinite row of equal parallel circular cylinders Q. J. Mech. appl. Math. 10:426-432

Vogel, S. (1981). Life in moving fluids. The physical biology of flow. Princeton University Press, New Jersey

Winter, J. E. (1973). The filtration rate of Mytilus edulis and its dependence on algal concentration, measured by a continuous automatic apparatus. Mar Biol. 22: 317-328

Wheaton, F. W (1977). Aquacultural engineering. Wiley \& Sons, New York

Manuscript first received: November 16, 1989

Revised version accepted: February 5, 1990 